\title{
KŪNO KULTŪROS IR KITŲ SPECIALYBIŲ MOKYTOJŲ SOCIALINIO BENDRAVIMO NUOSTATOS
}

\author{
Laimutė Kardelienė \\ Lietuvos kūno kultūros akademija, Kaunas, Lietuva
}

\begin{abstract}
Laimutė Kardelienė. Socialinių mokslų (edukologijos) daktarė, einanti profesorès pareigas Lietuvos kūno kultūros akademijos Sveikatos ir fizinio aktyvumo katedroje. LKKA Socialinių kūno kultūros ir sporto tyrimų laboratorijos vyriausioji mokslo darbuotoja. Mokslinių tyrimų kryptys: profesinis identitetas, profesinè komunikacija; sveikatos sociologija.
\end{abstract}

\begin{abstract}
SANTRAUKA
Moksliniai tyrimai apie ¿vvairiu specialybiu mokytoju statuso svarba rodo, kad mokytojai vertinami skirtingai. Neegzaminuojami dalykai edukacineje sistemoje vertinami prasčiau, nes jie yra periferiniai mokyklos pagrindinès instrumentinès funkcijos atžvilgiu. Teigiama, kad mokyklos direktoriai skatina kūno kultūros mokytoju ribiškumo ideja, nes pritaria kitu dalyku mokytoju nuomonei, kad mokykloje kūno kultūros mokytojams tenka (ir skiriama) mažesnė atsakomybe. Tokia situacija dažnai kelia tarp mokytoju itampa, kuri trikdo bendravima ir iš dalies lemia mokytoju vyru, ypač kūno kultūros specialistu, atsitraukima iš pedagoginès veiklos. Tyrimo tikslas - atskleisti kūno kultūros ir kitu specialybiu mokytoju socialinio bendravimo nuostatos ypatumus profesinio identiteto perspektyvoje.

Lyginamojo pobūdžio studijoje sukonstruota netikimybine 108 asmenu imtis, iš kuriu 24,3\% vyrai ir 75,7\% moterys. Tiriamieji atsitiktinai parinkti iš Kauno miesto viduriniu mokyklu. Ju socialinio bendravimo nuostatai atskleisti taikytas V. V. Boiko apklausos raštu metodas.

Tyrimu nustatyta, kad kūno kultūros mokytojams, lyginant su kitu specialybiu mokytojais, būdingesnè neigiama socialinio bendravimo nuostata. Neigiamesnè vyru nei moteru socialinio bendravimo nuostata gali büti susijusi su biologiniais veiksniais (galvos smegenu kairiojo pusrutulio veikla) ir tradiciškai suvokiamu vyro instrumentiniu vaidmeniu. Tyrimo rezultatai leidžia teigti, kad kūno kultūros mokytoju, ypač vyru, santykiai su kolegomis, mokiniais ir ju tèvais iš dalies nèra geri dèl žemo pedagogo profesijos prestižo vartotojiškoje visuomeneje.
\end{abstract}

Raktažodžiai: kūno kultūros mokytoju nuostata, bendravimas, socialinès situacijos, vyro instrumentinis vaidmuo, pedagogo profesijos prestižas.

\section{IVADAS}

$\tau$ vairiu specialybiu mokytoju statuso svarbos moksliniai tyrimai (Hargreaves, 1999; Geriausi mokiniai renka savo geriausius mokytojus, 2003; Panczyk, 2005) rodo, kad mokytojai vertinami skirtingai. Neegzaminuojami dalykai edukacinèje sistemoje vertinami prasčiau, nes jie yra periferiniai mokyklos pagrindinès instrumentinès funkcijos atžvilgiu. Dėl to smunka statusas tų mokytojų, kurie yra neakademinių mokomujų dalykų specialistai. Tyrimų duomenimis, mokiniai labiau- siai vertina kalbu ir matematikos mokytojus, prasčiau - antros šiuolaikinès kalbos mokytojus, dar blogiau - specialiujų dalykų mokytojus, tarp kurių kūno kultūros mokytojų statusas vienas žemiausių, ir dar prasčiau — pradinių klasių mokytojus ir ikimokyklinio amžiaus vaikų auklètojus (Hendry, 1975; Silverman, Subramaniam, 1999).

Lietuvoje, lyginant 2002 ir 2003 metu apklausų apie geriausiujų mokytoju pasiskirstymą pagal dèstomus dalykus rezultatus, tendencijos išlieka tos 
pačios - daugiausia balsų tiek tèvai, tiek mokiniai skyrè matematikos, lietuvių kalbos ir literatūros mokytojams (Geriausi mokiniai renka savo geriausius mokytojus, 2003). Pirmame penketuke išlieka tie patys mokomieji dalykai: matematika, lietuviu kalba ir literatūra, istorija, fizika ir anglu kalba. Tokia pat tendencija išryškejo ir $2006 \mathrm{~m}$. tyrimo metu (Turauskas, 2006).

Kai kurie tyrejai (Tjeerdsma, 1999; Laker, 2000) nustatè: kūno kultūros ir akademinius dalykus dèstantys mokytojai pritaria, kad kūno kultūros dalyko prestižas priklauso nuo mokyklos sporto komandų sèkmès. Aiškinama, kad elitinès vertybès yra persmelkusios visą švietimo sistemą, vadinasi, toks požiūris nèra būdingas tik kalbant apie kūno kultūros, kaip mokomojo dalyko, svarbą. Kolegos kūno kultūros mokytojus vertina kaip socialiai orientuotus, kurie geba mokinius sudominti, suburti ir mano, kad šie mokytojai gali teigiamai veikti moksleivių socialinę raidą. Todèl, pasak direktorių, jie vertinami kaip gabūs specialistai, tikintis, kad mokykloje atliks ir drausminamają funkciją (Laker, 2000; Beighle, Pangrazi, 2002; Сиваков, 2004). Dažnai mokyklos direktoriai skatina ribiškumo idėją, nes pritaria kitų mokytoju nuomonei, kad mokykloje kūno kultūros mokytojams tenka (ir skiriama) mažesnè atsakomybè. Tuo pat metu kolegos, rūpindamiesi mokyklos (ir savo pačių) prestižu, nori, kad kūno kultūros mokytojas taip treniruotų komandas, kad galètų prisidèti prie mokyklos įvaizdžio gerinimo. Atskleista kolegu pozicija dèl kūno kultūros mokytojo vaidmenų, kai administracija skiria drausmintojo vaidmeni, o kiti mokytojai - trenerio (sportininko), dažnai tampa priemone, kuri kelia itampą tarp kūno kultūros ir kitų specialybių mokytojų, ir instrumentu, trikdančiu kūno kultūros mokytojo bendravimą vietos bei profesinëje bendruomenejje.

Čia tiktú priminti visuomenés požiūrị i sportininką, iš dalies ir ị kūno kultūros mokytoją, kuri mokyklos bendruomenè mato kaip treneri, sportininką, o ne kaip ugdytoją. Dažnai manoma, kad sportininkas - tai dažniau išlavinti raumenys, nei mąstymas (Столяров, Самусенкова, 1996), todèl kūno kultūros mokytojai nepatenkinti bendradarbiavimu su kitų specialybiu mokytojais, juos slegia tokie reiškiniai kaip jų sekimas (ar priežiūra), homofobija (Macdonald, 1999). Taip gali susiformuoti neigiamesnè jų socialinio bendravimo nuostata nei kitu specialybių mokytojų. Norint patikrinti šią prielaidą atliktas tyrimas, kuriuo keltas toks probleminis klausimas: kokia kūno kultūros ir kitų specialybių mokytojų socialinio bendravimo nuostata?
Tyrimo tikslas - atskleisti kūno kultūros ir kitų specialybių mokytojų socialinio bendravimo nuostatos ypatumus.

\section{TYRIMO METODIKA}

Tiriamieji. Norint palyginti kūno kultūros mokytojų ir kitu specialybių mokytoju socialinio bendravimo nuostatas, sukonstruota netikimybinè imtis iš 108 asmenų, iš kurių $24,3 \%$ buvo vyrai ir $75,7 \%$ moterys, o tiriamujų amžiaus vidurkis $-38,29 \pm 0,8$ metu (vyru $-41,2 \pm 1,6$; moteru $-37,3 \pm 0,96)$. Tiriamieji atsitiktinai parinkti iš Kauno miesto vidurinių mokyklų, proporcingai skirstant $i$ tris grupes: pradinių klasiu mokytojai $(n=36)$; kūno kultūros mokytojai $(n=36)$; kitų dalykų mokytojai $(\mathrm{n}=36)$.

Tyrimo metodas. Tiriamuju socialinio bendravimo nuostatai atskleisti taikytas V. V. Boiko apklausos raštu metodas (Бойко, 2000). Klausimyną sudaro penkios teiginių skalès:

1. Neatskleistas žiaurumas bendraujant su žmonèmis ir sprendžiant apie juos, t. y. koks tiriamojo asmens požiūris į bendravimo situacijos dalyvius.

2. Atviras žiaurumas santykiuose su žmonèmis.

3. Pagristas negatyvus požiūris i̇ žmones, ypač apie juos samprotaujant.

4. Niurzgèjimas, kai asmuo perdètai neigiamai vertina negatyvius bendravimo ir socialinio gyvenimo faktus.

5. Negatyvi bendravimo su aplinkiniais patirtis.

Kiekvienam atskiros skalès teiginiui skiriamas atitinkamas balas už atsakymo variantą — sutinku arba nesutinku. Bendra visų skalių teiginių ivertinimo suma - 100 balų. Jei tiriamojo asmens surinkta balu suma didesnè nei vidutinis visos grupès balas, vadinasi, jo socialinio bendravimo nuostata yra neigiama.

Tyrimo procedūros. Kiekvienas tyrimo dalyvis buvo supažindintas su klausimyno pildymo instrukcija. Vadovautasi apklausos etiniais ir teisiniais principais. Kadangi asmeniškai bendrauta su mokytojais, tai užpildytą klausimyną iš tiriamuju buvo galima gauti iš karto.

Statistinė analizè. Tyrimo duomenims apskaičiuoti taikyti aprašomosios statistikos metodai ir statistinio reikšmingumo kriterijai. Norint nustatyti duomenų skirtumų tarp grupių statistini reikšmingumą taikytas Studento $t$ testas ir chi kvadrato kriterijus. Rezultatai įvardyti statistiškai reikšmingais, kai paklaidos tikimybè $\mathrm{p} \leq 0,05$, esant $95 \%$ patikimumui. 


\section{REZULTATAI}

Tyrimo duomenimis, vidutinis tirtu asmenų socialinio bendravimo nuostatos balas $-47,19 \pm 1,6$. Pagal sumini socialinio bendravimo nuostatos balą tarp kitu specialybių mokytojų neigiamesne nuostata išsiskiria kūno kultūros mokytojai (žr. 1 lent.).

Kūno kultūros mokytojams dažniau nei kitiems būdingas neatskleistas ir atviras žiaurumas bendraujant su žmonemis ir tokie bendravimo ypatumai kaip negatyvus požiūris į kitus, niurzgejjimas ir negatyvi bendravimo patirtis. Pagal šiuos komponentus išsiskiria ir kitu specialybiu mokytojai, nors jų socialinio bendravimo nuostatos suminis balas buvo kiek mažesnis nei kūno kultūros mokytojų. Mažiau neigiamos socialinio bendravimo nuostatos būdingos pradiniu klasiu mokytojams. Pastarieji iš kitų tiriamujų išsiskyrè kaip turintys teigiamesnę neatskleisto ir atviro žiaurumo bendraujant su kitais žmonėmis, pozityvaus požiūrio į kitus nuostatą. Visgi nors paminèti skirtumai, nusakantys tirtu grupių socialinio bendravimo nuostatas, yra statistiškai reikšmingi, jie dèl nedidelès tiriamuju imties leidžia kelti tik darbines hipotezes apie tokių nuostatų skirtumus visoje tirtuju populiacijoje.

Dauguma tiriamuju buvo moterys, tačiau 43 vyrų grupe leidžia preliminariai tikètis duomenu skirtumo lyties požiūriu (žr. pav.).

Iš paveikslo matyti, kad beveik visi socialinio bendravimo nuostatos požymiai (išskyrus neatskleistą žiaurumą ir niurzgèjimą) skiriasi pagal lytị. Ryškus šios nuostatos bendro įvertinimo balu skirtumas rodo, kad moterims rečiau nei vyrams būdinga neigiama socialinio bendravimo nuostata. Suskirsčius tiriamuosius pagal lyti i neigiamos (suminis balas didesnis nei 47) ir teigiamos (suminis balas mažesnis arba lygus 47 balams) socialinio bendravimo nuostatos grupes pastebèta, kad į nei-

\begin{abstract}
Pav. Socialinio bendravimo nuostatos kintamieji ir jų balų vidurkiai vyrų ir moterų grupèse
\end{abstract}

Pastaba. * - p < 0,$05 ; * *-$ $\mathrm{p}<0,01 ; * * *-\mathrm{p}<0,001$, lyginant vyru ir moteru duomenis.

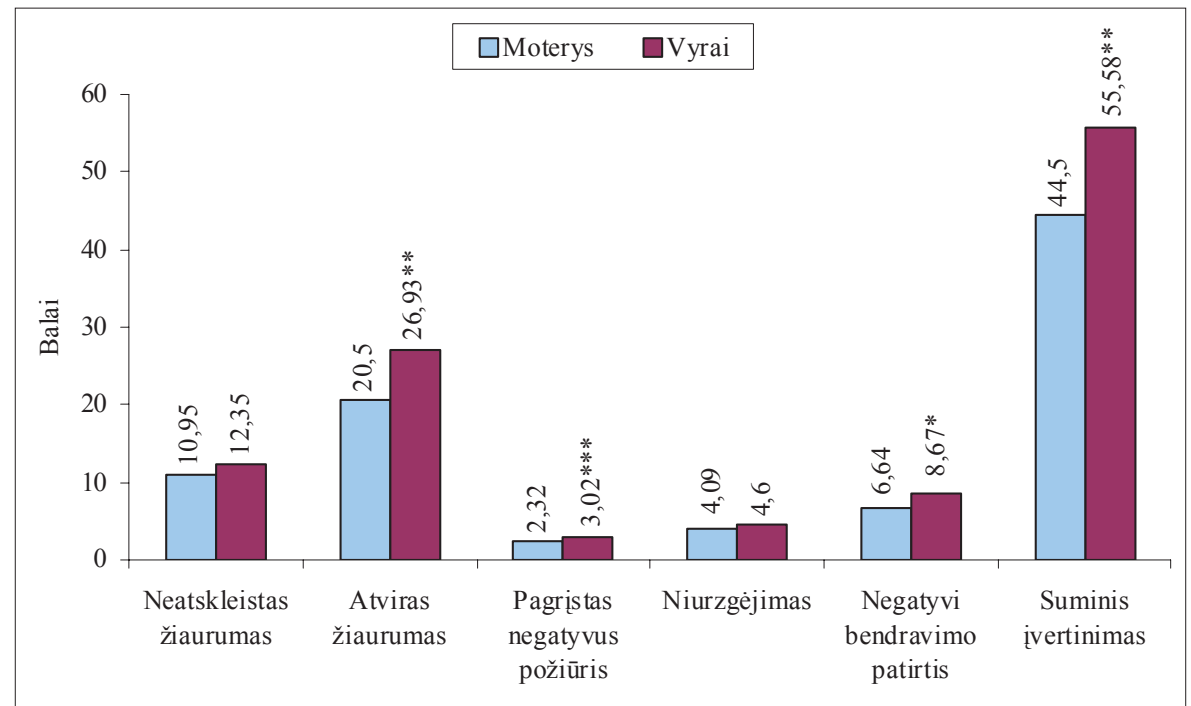

\begin{tabular}{|l|c|c|}
\hline Tiriamųjų grupès & Ivertinimo balas & 95\% PI \\
\hline Pradinių klasių mokytojai & $39,42 \pm 3,57$ & $32,16-46,67$ \\
\hline Kūno kultūros mokytojai & $52,67 \pm 3,57$ & $45,41-59,92$ \\
\hline Kitų dalykų mokytojai & $49,00 \pm 2,96$ & $42,98-55,02$ \\
\hline
\end{tabular}
$\mathrm{da}$; PI - pasikliautinasis intervalas; $\mathrm{F}=4,3 ; 1.1 .=4,0 ; \mathrm{p}<0,002$.

2 lentelè. Socialinio bendravimo nuostatos komponentų raiška tiriamujuc grupèse pagal lyti (\%)

Pastaba. * - p $<0,05$, lyginant vyru ir moteru duomenis.

\begin{tabular}{|l|c|c|c|c|}
\hline \multirow{2}{*}{ Nuostatos komponentai } & \multicolumn{4}{|c|}{ Komponentų raiška } \\
\cline { 2 - 5 } & \multicolumn{2}{|c|}{ Teigiamesne் } & \multicolumn{2}{c|}{ Neigiamesne் } \\
\cline { 2 - 5 } & Vyrai & Moterys & Vyrai & Moterys \\
\hline Neatskleistas žiaurumas & 41,9 & 53,7 & 58,1 & 46,3 \\
\hline Atviras žiaurumas & 39,5 & 54,5 & 60,5 & 45,5 \\
\hline Pagrịstas negatyvus požiūris į kitus & 37,2 & 52,2 & 62,8 & 47,8 \\
\hline Niurzgèjimas & 48,8 & $65,7 *$ & 51,2 & 34,3 \\
\hline Negatyvi bendravimo patirtis & 25,6 & 41,0 & 74,4 & 59,0 \\
\hline
\end{tabular}


giamos nuostatos grupę patenka daugiau vyrų nei moteru (atitinkamai 86,0 ir 67,9\%; $\mathrm{p}<0,02$ ). Taip tiriamieji suskirstyti ir pagal atskirus socialinio bendravimo nuostatos komponentus (žr. 2 lent.). Tiriamieji, kurių vieno ar kito nuostatos komponento raiška buvo didesnè už grupès vidurki, vertinti kaip turintys neigiamesnę nuostatą to ar kito komponento atžvilgiu, ir atvirkščiai.

Lenteleje pateikti duomenys rodo, kad statistinio reikšmingumo požiūriu labiausiai skiriasi tokia socialinio bendravimo vyrų ir moterų nuostata kaip niurzgejjimas, kuris būdingesnis tirtiems vyrams. Gautas panašus procentinès išraiškos skirtumas ir kitų nuostatos dèl komunikacijos komponentų atžvilgiu, ir tai patvirtina neigiamesnę vyrų komunikacijos nuostatą.

\section{REZULTATŲ APTARIMAS}

Nustatyta, kad subjektyvios gerovès komponentai, susiję su tokiais asmenybės bruožais kaip optimizmas, savęs vertinimas, neurotiškumas, ekstraversiškumas, atvirumas naujai patirčiai, sutarimas su kitais, są̌ziningumas, yra santykiškai susiję ir su asmenybès predispozicija jaustis laimingam (Šilinskas, Žukauskienè, 2004), todèl tyrimo metu gilintasi i socialinio bendravimo nuostatos ypatumus. Socialinio bendravimo nuostata gali būti traktuotina kaip mokytojo / mokytojos subjektyvios gerovès išgyvenimo apraiška. Taip teigti galima, nes ši nuostata formuojasi veikiant ivairiems veiksniams, tarp kurių vieni svarbiausių — asmenybès emocinès reakcijos ì gyvenimo ivvykius bei išgyvenama įtampa dèl sociokultūrinès aplinkos lūkesčių apie atliekamus vaidmenis profesinèje ir asmeninèje veikloje. Tad kūno kultūros mokytojų, kaip esančių tarp ribinius vaidmenis turinčiu pedagogų, neigiamą socialinio bendravimo nuostatą dera aiškinti tyrimais, kurie rodo, kad ribinius vaidmenis mokykloje atliekantys mokytojai, ypač kūno kultūros, yra bendraujantys, entuziastingi, nors ir agresyvūs (Hendry, 1975; Laker, 2000). Pastarojo dalyko mokytojai labiau orientuoti i pasiekimus, del to kartais stokoja socialinio ižvalgumo, bendrojo išprusimo (Blinstrubas, 2002; Curtner-Smith, 2001), noro dirbti mokytoju (Šeščilienè, 2001; Ivaškienè, Baltaplūkytè, 2004; Karanauskienè, Kardelis, 2005). Jie ieško situacijų, kad galètų dominuoti (Silverman, Subramaniam, 1999). Taip pat teigiama, kad kūno kultūros mokytojai ši jausmą išgyvena ir bendraudami su mokiniais, kai jiems demonstruoja draugiškumą, ir su galingesniais grupès nariais (tarkim, mokyklos administracija), kai rodo jiems nuolankumą. Tai leidžia manyti, kad bendraudami kūno kultūros mokytojai išgyvena dèl tokio vaidmens naštos. Tokia situacija gali lemti ir jų socialinio bendravimo nuostatos neigiamus ypatumus, lyginant su kitu specialybių mokytojais. Tyrimo rezultatai taip pat leidžia teigti, kad kūno kultūros mokytojų, ypač vyrų, santykiai su kolegomis, mokiniais ir jų tevais dèl žemo pedagogo profesijos prestižo vartotojiškoje visuomenèje iš dalies nèra geri.

Profesinius kūno kultūros mokytojų gebèjimus kaip vientisą sistemą, lemiančią profesinès veiklos sèkminguma, sudaro daugelis komponentu, kurie sujungia ir bendruosius pedagoginius, ir dalykinius (motorinius-pedagoginius) (Бурлакова, 2000). Profesiniai kūno kultūros mokytojo gebejjimai determinuoti asmenybinių, morfologinių, fiziologinių, psichologiniu, psichosocialinių integralios asmenybès požymių. Be to, profesiniu gebejjimu struktūra priklauso nuo lyties. Moters veikla labiau susijusi su psichologiniais komponentais (dèmesio patvarumu, valia, emociniu stabilumu), vyru - su morfologiniais (ūgiu, svoriu ir jų santykiu). Kūno kultūros veikloje pastebimas ir socialinis-psichologinis lyčiu skirtumas: moterys praktiškesnès ir rūpestingesnès, siekiančios mokytojo karjeros per pamokas ugdant mokinių kūno kultūrą, o vyrai išsiskiria aukštesniu intelektu, jie radikalesni, savarankiški, orientuoti į mokyklos sporto komandu treniravimą, o mokymą per pamokas traktuoja kaip karjeros netikètumą (Curtner-Smith, 2001). Tyrimu atskleistus vyru ir moteru socialinio bendravimo nuostatos skirtumus aiškina psichologinès studijos, teigiančios, kad moterys save apibūdina kaip empatiškas, gebančias suprasti kitų žmoniu jausmus (Мельникова, 2003). Taip pat nustatyta, kad moterys geriau nei vyrai atkoduoja aplinkinių emocinius išgyvenimus ir juos interpretuoja, o tai lemia tradicinius vyrų ir moteru vaidmenis (Parsons, 1949 - cit. iš: Lemme, 2003). Moteriškas raiškos vaidmuo suprantamas kaip ryšiu užmezgimas ir palaikymas, nes moterys dažniausiai studijuoja socialines paslaugas, humanitarinius mokslus, mokytojų rengimą ir pedagogiką (Žukauskienè, Šakalytė, 2003), o vyrų tradicinis interpretacinis vaidmuo juos orientuoja į tikslą ir laimejjimus, taigi ir vyravima, nepriklausomybę, racionalumą, todèl daugiau jų studijuoja fizikos mokslus, inžineriją, kompiuteriją, statybą (plačiau žr. ten pat).

Gautą neigiamesni vyrų socialinio bendravimo nuostatos rezultatą paaiškina ir tas faktas, kad vyrai ir moterys apskritai skirtingai traktuoja sėkmę 
darbe: moterims svarbiausia santykiai, bendradarbiavimo kultūra, vyrams - pasiekimai, sẻkmé, kuri suprantama kaip statusas, itaka, veiklos nauda (Lemme, 2003). Be to, neigiamesnè vyru socialinio bendravimo nuostata gali būti susijusi ir su biologiniais veiksniais (galvos smegenų kairiojo pusrutulio veikla) ir su tradiciškai suvokiamu vyro instrumentiniu vaidmeniu (Мельникова, 2003). Kadangi aprašomo tyrimo metu moterys turi teigiamesnę socialinio bendravimo nuostatą nei vyrai, žvilgtelta ir $\mathfrak{i}$ kitus Lietuvoje atliktus tyrimus. Teigini, kad moterims svarbūs darbiniai santykiai, patvirtina privačiose struktūrose atliktas tyrimas, kuriuo nustatyta, kad dirbančios moterys rečiau nei vyrai patenkintos santykiais organizacijoje, savo padetimi ir mano, kad vyrams lengviau siekti karjeros (Daukantienè, 2006). N. Petkevičiūtès ir A. Saudargaitès (2006) tyrimas atskleide, kad labiausiai darbine veikla nusivylusios $31-40 \mathrm{~m}$. moterys ir tos, kurios dirba privataus kapitalo organizacijose. Visos tiriamosios retokai patenkintos bendravimu darbo vietose, nes $30 \%$ jaučiasi nepripažintos kolegų, o tarp nepasitenkinimo darbu veiksnių kaip svarbiausias nurodytas mažas ir netinkamas atlygis (38\%). Kadangi mūsų tyrimas atliktas biudžetinèse organizacijose, tai iš dalies lemia ir kitus rezultatus. Mat ir minètosios autorès nurodo, kad fiziniai (susiję su darbo sąlygomis) stresoriai dažniau nei socialiniai veikia biudžetinèse organizacijose dirbančias moteris.
Apibendrinant tyrimo rezultatus galima teigti, kad neigiamą socialinio bendravimo nuostatą gali lemti ir tokios asmenybès savybès kaip optimizmas, sutarimas su kitais, savigarba, ekstraversiškumas, sąžiningumas, t. y. kuo mažiau asmeniui būdinga kuri nors savybè, tuo didesnis jo / jos neigiamas emocingumas, taigi ir neigiama bendravimo nuostata. Tokie asmenys yra žemesnio subjektyvios gerovès išgyvenimo lygio, ir tai leidžia kelti prielaidą, kad jie retai patenkinti ir darbu, ir laisvalaikiu, ir artimais ryšiais.

\section{IŠVADOS}

1. Tirtiems kūno kultūros mokytojams, lyginant su kitų specialybių mokytojais, būdingesnè neigiama socialinio bendravimo nuostata, pasireiškianti neatskleistu ir atviru žiaurumu bendraujant su kitais žmonèmis bei susidarant nuomone apie juos. Kitų specialybių mokytojai labiau nei kūno kultūros ir pradinių klasių mokytojai išsiskiria negatyviu požiūriu i bendravimo partnerius bei niurzgèjimu.

2. Tyrimu atskleista neigiamesnè vyrų nei moterų socialinio bendravimo nuostata, kuriai būdingas atviras žiaurumas bendraujant su žmonėmis, pagrịstas negatyvus požiūris į kitus, ypač apie juos samprotaujant, ir negatyvi bendravimo su aplinkiniais patirtis.

\section{LITERATŪRA}

Beighle, A., Pangrazi, R. P. (2002). The seven habits of highly effective physical education teachers. Teaching Elementary Physical Education, 13 (4), 6-9.

Blinstrubas, A. (2002). Būsimuju mokytoju bendrasis išprusimas kaip edukacinès diagnostikos objektas. Acta Paedagogica Vilnensia, t. 9, 52-63.

Curtner-Smith, M. D. (2001). The occupational socialization of a first-year physical education teacher with a teaching orientation. Sport, Education and Society, 6 (1), 81-105.

Daukantienè, N. (2006). Darbo rinkos pokyčiai Lietuvoje: moteru ir vyru padèties aspektai. Filosofija. Sociologija, 4, 46-54.

Geriausi mokiniai renka savo geriausius mokytojus. (2003). Specialus informacinis leidinys. Vilnius.

Hargreaves, A. (1999). Keičiasi mokytojai, keičiasi laikai. Vilnius: Tyto Alba.

Hendry, L. B. (1975). Survival in a marginal role: The professionhal identity of the physical education teacher. British Journal of Sociology, 26 (4), 465-477.

Ivaškienè, V., Baltaplūkytè, N. (2004). Lietuvos ir Vokietijos studentų požiūris ì studijas ir kūno kultūrą. Küno kultūra, sportas ir mokslas studentu gyvenime: tarptautinés mokslinès konferencijos pranešimai. Sud. R. Mažeikienė. Kaunas: LKKA. P. 39-48.
Karanauskiene, D., Kardelis, K. (2005). The relationship between students' academic identity and academic achievements. Social Sciences, 1 (47), 62-71.

Laker, A. (2000). Beyond the Boundaries of Physical Education: Educating Young People for Citizenship and Social Responsibility. London and New York: RoutledgeFalmer.

Lemme, B. H. (2003). Suaugusiojo raida. Kaunas: Poligrafija ir informatika.

Macdonald, D. (1999). The "professional" work of experienced physical education teachers. Research Quarterly for Exercise and Sport, 70 (1), 41-55.

Panczyk, W. (2005). School physical education and the perspectives of physical activity in the consumer society. In J. Kosiewicz (Eds.), Sport, Culture and Society. Warsaw: Akademia Wychowania Fizycznego. P. 371-379.

Petkevičiūtè, N., Saudargaitè, A. (2006). Moterų streso ypatumai skirtingo tipo organizacijose. Organizaciju vadyba: sisteminiai tyrimai, 39, 189-202.

Silverman, S., Subramaniam, P. R (1999). Student attitude toward physical education and physical activity: A review of measurement issues and outcomes. Journal of Teaching in Physical Education, 19 (1), 97-125.

Šeščilienè, I. M. (2001). Būsimujų kūno kultūros mokytojų 
pažintinio kryptingumo ypatumai. Ugdymo psichologija, t. 4, $1(8), 38-41$.

Šilinskas, G., Žukauskienè, R. (2004). Subjektyvios gerovès išgyvenimas ir su juo susiję veiksniai vyru imtyje. Psichologija, 30, 47-58.

Tjeerdsma, B. L. (1999). Physical education as a social and emotional development laboratory. Teaching Elementary Physical Education, 10 (4), 12-16.

Turauskas, L. (2006). 2002-2006 metu geriausiuju abiturientu ir ju tèvu apklausu duomenu palyginamosios analizès pateiktis [žr. 200812 09]. Prieiga internetu: http://src.takas.lt/gallery/svetimas/geriausi/docs/Telekom mokiniai2006_pristatymas.ppt

Žukauskienè, R., Šakalyte, J. (2003). Moteru profesine karjera. Vilnius: A. Malinausko It.

Бойко, В. В. (2000). Методика диагностики коммуникативной установки. В Д. Я. Райгородский (Ред.), Психологическе тесты, 2, 298-302. Самара: Издательский дом «БАХРАХ».
Бурлакова, Н. Ю. (2000). Профессиональные способности в структуре интегральной индивидуальности учителя физической культуры. На правах рукописи. Пермь: Пермский государственный педагогический университет. Prieiga internetu: <http://diss.rsl.ru/ diss/03/0001/030001023/pdf>.

Мельникова, А. А. (2003). Язык и национальный характер. Взаимосвязь структуры языка и ментальности. Санкт-Петербург: Речь.

Сиваков, В. И. (2004). Педагогическое воздействие на психоэмоциональное напряжение школьников на уроках физической культуры. Физическая культура: воспитание, образование, тренировка, 1, 17-19.

Столяров, В. И., Самусенкова, В. И. (1996). Современный спорт как феномен кулътуры и пути ево интеграции с искуством. Спорт и искуство: алтернативаединство-синтез, 49-164.

\title{
ATTITUDES OF TEACHERS OF PHYSICAL EDUCATION AND OTHER SUBJECTS TOWARDS SOCIAL COMMUNICATION
}

\author{
Laimutė Kardelienè \\ Lithuanian Academy of Physical Education, Kaunas, Lithuania
}

\begin{abstract}
Academic research on the hierarchy of statuses of teachers of various subjects demonstrate that teachers at schools are valued differently regarding the subject they teach. It has been established that subjects which are not concluded by exams typically bear low status as they are peripheral in the context of the main instrumental function of the school. It has been claimed that school directors corroborate the idea of limitedness of physical education teachers since they share the opinion of other teachers that physical education teachers bear (and are attributed) lower responsibility. This situation frequently causes friction among teachers which hampers communication and partially conditions the withdrawal of males (especially specialists of physical education) from pedagogical activity. The aim of the study was to reveal the attitude of teachers of physical education and other subjects towards social communication from stand point of professional identity.

In the comparative study, we developed a convenience sample of 108 individuals including $24.3 \%$ of males and $75.7 \%$ of females. The participants of the study were selected from Kaunas secondary schools. In order to reveal the attitudes of the participants to social communication, the questionnaire method by V. V. Boiko was applied.

It was established that physical education teachers in comparison to teachers of other subjects more frequently had negative attitudes towards the participant(s) of a communicative situation. It is possible to presume that more negative attitudes of males rather than females to social communication may be related to both biological factors (activity of the left hemisphere of the brain) and to the traditionally-conceived instrumental role of males. The results of the analysis may validate the claim that the relationship of physical education teachers, especially males, with their colleagues, students and their parents are partially poor due to the low prestige of the pedagogical work in the consumer society.
\end{abstract}

Keywords: attitudes of physical education teachers, communication, social situations, instrumental role of males, prestige of the pedagogical profession.

Gauta 2008 m. spalio 2 d.

Received on October 2, 2008

Priimta 2008 m. gruodžio $9 \mathrm{~d}$.

Accepted on December 9, 2008
Laimutė Kardelienè

Lietuvos kūno kultūros akademija

(Lithuanian Academy of Physical Education)

Sporto g. 6, LT-44221 Kaunas

Lietuva (Lithuania)

Tel +370 37302637

E-mail laimutekk@gmail.com 